\title{
Comparison of procedures for assessing nitrogen retention in chicks*
}

\author{
By W. R. SANSLONE AND R. L. SQUIBB \\ Laboratories of Disease and Environmental Stress, Rutgers, \\ The State University, New Brunswick, New fersey \\ (Received 21 April 1961-Revised 12 October 1961)
}

The nitrogen balance technique is widely used for protein metabolism studies and in this laboratory is being applied to research on interrelationships between diet and disease (Squibb, I96r). Recently, however, the experimental error resulting from $\mathrm{N}$ losses during $\mathrm{N}$ balance experiments has been stressed and the integrity of some $\mathrm{N}$ balance data questioned (Wallace, 1959). In this report the $\mathrm{N}$ retained by growing chicks, expressed as difference between $\mathrm{N}$ intake and excretion, is evaluated by two calculation procedures based on carcass analysis.

\section{EXPERIMENTAL}

Carcass analysis

For the purpose of calculations explained below, it was necessary to arrive at a reliable mathematical factor for calculating total body $\mathrm{N}$ of chicks at the time they were placed on $\mathrm{N}$ balance tests without destroying the animals. Thus, twenty representative chicks, ten from each of two different hatches, were reared on a stock diet until they were 10 days of age. The chicks were then starved for $3 \mathrm{~h}$ and killed by careful dislocation of the neck. Each carcass was analysed for total $\mathrm{N}$ and light petroleumextractable material by modifications of the hydrochloric acid hydrolysis procedures used by Ackerson, Blish \& Mussehl (1935) and Rand (1957).

These modified procedures consisted of placing individual carcasses in $600 \mathrm{ml}$ beakers containing about $100 \mathrm{ml}$ of conc. $\mathrm{HCl}$. The exact amount of $\mathrm{HCl}$ depended upon the weight of the animal before it was killed, $\mathrm{I} \mathrm{ml}$ of acid being added for each $\mathrm{g}$ of body-weight. The contents of the beakers were digested for $\mathrm{I} 2 \mathrm{~h}$ on a copper steambath. The digested material was placed in a freezer overnight and the solid upper layer of fat removed. The hydrolysate was placed in a 21 . separating funnel and extracted four times with $100,80,60$, and $40 \mathrm{ml}$ of light petroleum (b.p. 30-60\%). The extracts were added to the previously separated fat. The combined extracts were then washed with distilled water and the washings added to the acid hydrolysate. The lightpetroleum layer containing the previously separated fat was placed in a tared beaker, the solvent was removed by warm moving air and the total carcass fat was measured.

* Paper of the Journal Series, Rutgers, The State University, New Brunswick, N.J. 
The acid hydrolysate was placed in a 1 . volumetric flask and diluted to volume with distilled water. Two $5 \mathrm{ml}$ portions were analysed for $\mathrm{N}$ by micro-Kjeldahl procedures (Association of Official Agricultural Chemists, 1955).

\section{Nitrogen balance}

For each of four $\mathrm{N}$ balance experiments, sixty newly hatched White Leghorn cockerels were fed on a stock diet $a d$ lib. for a Io-day period. During the last 3 days of this period, the individual weight gains observed in each group of sixty birds were used as the basis for selecting chicks for each trial. The chicks thus selected were placed in individual metabolism cages (Sanslone \& Squibb, 1961) and, after a $24 \mathrm{~h}$ equilibration period, feeding and collection of excreta began. Total excreta were collected every $24 \mathrm{~h}$ for 4 days in Expts I and 2, 7 days in Expt 3, and 8 days in Expt 4 . The excreta were placed in $\mathrm{I} 1$. jars containing $100 \mathrm{ml}$ distilled water and 3 drops of Antifoam B (Dow Corning, 600 Fifth Avenue, New York, N.Y.) and homogenized with a Servall Omni-Mixer (Ivan Sorvall Inc., Norwalk, Conn.). After this preliminary preparation the samples were diluted with water to $25^{\circ} \mathrm{ml}$. Duplicate $3 \mathrm{ml}$ samples of the final mixture were analysed for total $\mathrm{N}$ by micro-Kjeldahl procedures.

The $\mathrm{N}$ content of the diets given during the $\mathrm{N}$ balance tests was determined by Kjeldahl's method and the amount of diet consumed daily by each chick measured; $\mathrm{N}$ intake was calculated from these values. $\mathrm{N}$ retention was estimated by subtracting $\mathrm{N}$ excreted from $\mathrm{N}$ intake.

At the conclusion of each $\mathrm{N}$ balance experiment the chicks were starved for $3 \mathrm{~h}$, killed, and analysed for total $\mathrm{N}$ and light petroleum-extractable material by the procedures described on p. 59 .

\section{RESULTS}

The values in Table I show that the $\mathrm{N}$ content of the fat-free carcass of the twenty representative I0-day-old chicks averaged $2 \cdot 86 \pm 0.02 \%$. The uniformity of these values is in accord with the findings of Widdowson \& McCance (1956) who showed for rats that the $\mathrm{N}$ content of the fat-free body at a given stage of maturity is constant. The total body $\mathrm{N}$ of a living ro-day-old chick before the beginning of a $\mathrm{N}$ balance trial, therefore, was calculated by weighing the bird, subtracting $9.5 \mathrm{~g}(4.2 \mathrm{~g}$ to account for intestinal contents and $5.3 \mathrm{~g}$ for light petroleum-extractable material) and multiplying the remainder by $2 \cdot 86 \%$.

Table I. Mean body nitrogen content of ro-day-old White Leghorn cockerels as determined by carcass analysis

\begin{tabular}{|c|c|c|c|c|c|c|c|c|}
\hline $\begin{array}{c}\text { Expt } \\
\text { no. }\end{array}$ & $\begin{array}{c}\text { No. } \\
\text { of } \\
\text { birds }\end{array}$ & $\begin{array}{l}\text { Body- } \\
\text { weight } \\
\text { (g) }\end{array}$ & $\begin{array}{c}\text { Body- } \\
\text { weight } \\
\text { after } 3 \mathrm{~h} \\
\text { starvation } \\
\text { (g) }\end{array}$ & $\begin{array}{l}\text { Intestinal } \\
\text { contents } \\
\text { (g) }\end{array}$ & $\begin{array}{l}\text { Light- } \\
\text { petroleum } \\
\text { extract } \\
\text { (g) }\end{array}$ & $\begin{array}{c}\text { Fat-free } \\
\text { body } \\
\text { mass } \\
(g)\end{array}$ & $\begin{array}{l}\text { Total } \\
\text { carcass } \mathrm{N} \\
\text { (mg) }\end{array}$ & $\begin{array}{c}\text { Fat-free } \\
\text { body N* } \\
(\%)\end{array}$ \\
\hline$I$ & 10 & II $5 \cdot 8$ & II $2 \cdot 4$ & $\begin{array}{l}3 \cdot 6 \\
.8\end{array}$ & $5 \cdot 96$ & $106 \cdot 4$ & 3031 & $2.85 \pm 0.02$ \\
\hline 2 & 10 & IOI'I & $96 \cdot 3$ & $4 \cdot 8$ & $4 \cdot 61$ & $9 \mathrm{I} \cdot 7$ & 2620 & $2.86 \pm 0.02$ \\
\hline Mean & -- & - & - & $4 \cdot 2$ & $5 \cdot 28$ & - & - & $2.86 \pm 0.02$ \\
\hline
\end{tabular}


Table 2. Two calculation procedures for assessing nitrogen retention in chicks

\begin{tabular}{|c|c|c|c|c|c|c|c|c|c|}
\hline \multirow[b]{2}{*}{$\begin{array}{c}\text { Expt } \\
\text { no. }\end{array}$} & \multirow[b]{2}{*}{$\begin{array}{c}\text { No. } \\
\text { of } \\
\text { birds }\end{array}$} & \multirow[b]{2}{*}{$\begin{array}{l}\text { Days } \\
\text { on } \\
\text { balance }\end{array}$} & \multicolumn{5}{|c|}{ Procedure I } & \multicolumn{2}{|c|}{ Procedure 2} \\
\hline & & & $\begin{array}{c}\mathrm{N} \text { re- } \\
\text { tained } \\
\text { during } \\
\mathrm{N} \text { balance } \\
(a) \\
(\mathrm{mg})\end{array}$ & $\begin{array}{c}\text { Calculated } \\
\text { body } \\
\mathrm{N} \text { at } \\
\text { beginning } \\
\text { of } \mathrm{N} \\
\text { balance } \\
(\mathrm{b}) \\
\text { (mg) }\end{array}$ & $\begin{array}{l}\text { Predicted } \\
\text { body } N \text { at } \\
\text { end of } \\
N \text { balance } \\
(c) \\
(a+b) \\
(\mathrm{mg})\end{array}$ & $\begin{array}{c}\text { Deter- } \\
\text { mined } \\
\text { body } N \\
\text { at end } \\
\text { of } N \\
\text { balance } \\
(d) \\
(\mathrm{mg})\end{array}$ & $\begin{array}{c}\text { Predicted } N \\
\text { recovered by } \\
\text { carcass } \\
\text { analysis* } \\
(e) \\
(c / d \times \text { roo }) \\
(\%)\end{array}$ & $\begin{array}{c}\text { Gain in } \\
\text { body } N \\
\text { during } \\
\text { balance } \\
(f) \\
(d-b) \\
(\mathrm{mg})\end{array}$ & $\begin{array}{c}\text { Retained N } \\
\text { recovered } \\
\text { in carcass* } \\
(g) \\
(a / f \times \text { roo }) \\
(\%)\end{array}$ \\
\hline I & ro & 4 & 833.3 & $3054^{\circ} 5$ & $3887 \cdot 8$ & $38 \times 7 \cdot 2$ & $101 \cdot 84 \pm 0.53$ & $762 \cdot 7$ & I $12.25 \pm 3.53$ \\
\hline 2 & IO & 4 & $974 \cdot 6$ & $2608 \cdot 3$ & 3582.9 & $3662 \cdot 8$ & $97.52 \pm 0.83$ & 1054.5 & $92 \cdot 44 \pm 2 \cdot 96$ \\
\hline 3 & 10 & 7 & $1718 \cdot 8$ & $2665 \cdot 5$ & $43^{8} 4 \cdot 3$ & $4352 \cdot 3$ & $100.91 \pm 0.86$ & 1686.8 & $103.35 \pm 2.69$ \\
\hline 4 & 5 & 8 & $3001 \cdot 0$ & $2759^{\circ} 9$ & $5760 \cdot 9$ & $54 \times 2 \cdot 0$ & $107 \cdot 10 \pm 1 \cdot 30$ & $2652 \cdot 1$ & I I $3.32 \pm 2.75$ \\
\hline Mean $\dagger$ & - & - & - & - & - & - & $101 \cdot 00 \pm 0 \cdot 63$ & - & $104.20 \pm 2.48$ \\
\hline
\end{tabular}

Table 2 illustrates the design of the experiment, giving the number of animals and the number of days each group of birds was maintained on a balance trial. The information in this table is arranged to explain the two procedures used for evaluating $\mathrm{N}$ retention. In procedure $\mathrm{I}$ the $\mathrm{N}$ content of each animal at the end of $\mathrm{N}$ balance was predicted $(c)$ by adding the calculated total $\mathrm{N}$ at the beginning $(b)$ and the $\mathrm{N}$ retained during balance (a). These (predicted) body $\mathrm{N}$ values were found to be Ior $\cdot 0 \pm 0.6 \%$ of those values determined by carcass analysis at the end of $\mathrm{N}$ balance $(d)$.

In procedure 2 (Table 2) the calculated body $\mathrm{N}$ values at the beginning of $\mathrm{N}$ balance (b) were subtracted from the body $\mathrm{N}$ values individually determined by carcass analysis at the end of the balance experiments $(d)$. Respective differences $(f)$ constituted an estimate of the gain in body $\mathrm{N}$ for each chick during the balance period. A comparison of these estimates with the $\mathrm{N}$ retention values obtained by the usual $\mathrm{N}$ balance calculations $(a)$ showed that $\mathrm{N}$ retention was $104.2 \pm 2.5 \%$ of the body $\mathrm{N}$ gain $(\mathrm{g})$.

\section{DISCUSSION}

In procedure $\mathrm{I}$, body $\mathrm{N}$ predictions were $\mathrm{x} \cdot 0 \%$ greater than the $\mathrm{N}$ values determined by carcass analysis. In procedure 2 , the $\mathrm{N}$ retention values obtained by difference between intake and excretion exceeded body $\mathrm{N}$ gains by $4 \cdot 2 \%$. The higher value observed in the latter procedure reflects the use of final carcass $\mathrm{N}$ values in the first instance and body $\mathrm{N}$ gain in the second procedure as the basis on which to assess the same discrepancy.

The small errors being considered, i.e. $\mathrm{x} \cdot 0$ and $4 \cdot 2 \%$, could have resulted from overestimating $\mathrm{N}$ retention, underestimating body $\mathrm{N}$ at the beginning of $\mathrm{N}$ balance, or a combination of both. It does not appear plausible that the body $\mathrm{N}$ values at the beginning of $\mathrm{N}$ balance are incorrect because they are based primarily on the factor $2.86 \%$ which has a small standard error $(0.02 \%)$. Further, $\mathrm{N}$ retention figures are more susceptible to experimental error because they are the sum of values obtained 
from several feeding periods, faecal collections, and analyses. Thus, the small errors under consideration may be related to slight overestimation of $\mathrm{N}$ retention, which in turn may be a reflection of small $\mathrm{N}$ losses.

Since the discrepancies between predicted body $\mathrm{N}$ and determined body $\mathrm{N}$ (procedure 1 ), and between $N$ retention and body $N$ gain (procedure 2) were small, the results presented demonstrate that it is possible to establish the accuracy of $\mathrm{N}$ balance data within the limits of biological error. Large discrepancies, however, would indicate the need for more refined laboratory technique.

In addition to forming the basis for evaluating $\mathrm{N}$ retention data obtained by the usual $\mathrm{N}$ balance procedures, the calculation of body $\mathrm{N}$ gains as detailed in procedure 2 (Table 2) constitutes another means for estimating $\mathrm{N}$ retention. This procedure has an advantage over the conventional $\mathrm{N}$ balance technique in that it is less laborious than the excreta collection and analytical methods applied in the usual $\mathrm{N}$ balance methodology.

The obvious disadvantage in estimation of $\mathrm{N}$ retention by carcass analysis is that only the total $\mathrm{N}$ gain for the entire balance period can be determined for any individual animal. Thus, the daily $\mathrm{N}$ retention responses resulting from various daily treatments, for example, can be measured only by the conventional $\mathrm{N}$ balance technique with daily collection of excreta.

Results with several species, including man, have been reported (Mitchell, 1949; Holmes, Jones \& Stanier, 1954; Anonymous, 1955) showing positive $\mathrm{N}$ retentions with no concomitant increase in body-weight. As an explanation of this phenomenon, a hypothetical pathway for $\mathrm{N}$ metabolism was proposed (Costa, I960) suggesting the elimination of a $\mathrm{N}$-containing metabolite through respiration. If such a pathway exists in the rapidly growing chick, it would obviously negate the usefulness of using this laboratory animal for conventional $\mathrm{N}$ balance studies. However, since almost all of the $\mathrm{N}$ retention reported here may be accounted for in body $\mathrm{N}$ gains during the balance period, it is doubtful if any significant amount of $\mathrm{N}$ is eliminated through any route other than urine and faeces. Therefore, the valid use of the chick for $\mathrm{N}$ balance studies appears to be substantiated.

\section{SUMMARY}

1. Individual nitrogen retention values obtained in four balance experiments with a total of thirty-five chicks were evaluated by collection of excreta and also by carcass analysis.

2. The $\mathrm{N}$ content of each animal at the end of $\mathrm{N}$ balance was predicted by adding the value for calculated body $\mathrm{N}$ at the beginning of balance to that for the calculated $\mathrm{N}$ retained during balance. These predicted values were ror.$\%$ of the $\mathrm{N}$ values determined directly by carcass analysis.

3. Calculated $\mathrm{N}$ retained during balance was $104.2 \%$ of the body $\mathrm{N}$ gain determined by subtracting calculated body $\mathrm{N}$ at the beginning of balance from the total body $\mathrm{N}$ obtained by carcass analysis at the end of balance.

4. The findings indicate that the immature cockerel chick is an acceptable animal for standard $\mathrm{N}$ balance studies. 
We acknowledge the laboratory assistance of Miss Portia Burt. The work was supported in part by U.S. Public Health Service Grant E-3645.

\section{REFERENCES}

Ackerson, C. W., Blish, M. J. \& Mussehl, R. E. (1935). Res. Bull. Nebr. agric. Exp. Sta. no. 80. Anonymous (1955). Nutr. Rev. 13, 42 .

Association of Official Agricultural Chemists (1955). Official Methods of Analysis, 8th ed. Washington: Association of Official Agricultural Chemists.

Costa, G. (1 960). Nature, Lond., I88, 549.

Holmes, E. G., Jones, E. R. \& Stanier, M. W. (1954). Brit. F. Nutr. 8, 173.

Mitchell, H. H. (1949). Arch. Biochem. 21, 335.

Rand, N. T. (1957). The utilization of fat by the growing chick. Doctoral Thesis, University of Illinois, Urbana, Ill.

Sanslone, W. R. \& Squibb, R. L. (1961). Poult. Sci. 40, 816.

Squibb, R. L. (196r). Poult. Sci. 40, 425.

Wallace, W. M. (1959). Fed. Proc. 18, 1125.

Widdowson, E. M. \& McCance, R. A. (1956). Brit. F. Nutr. ro, ${ }^{6} 63$. 